\title{
Performance Evaluation of Continuous Flow Aerobic Granular Sludge Configurations
}

\begin{abstract}
ELENA ELISABETA MANEA, COSTEL BUMBAC*
National Research and Development Institute for Industrial Ecology - ECOIND, $71-73$ Drumul Podul Dambovitei Str., 060652, Bucharest, Romania

Increasing the efficiency and capacity of existing wastewater treatment plants can be carried out by using intensive biological processes. One of the currently studied biological solutions consists in using aerobic granular sludge in order to achieve both organics and nutrients removal simultaneously in one tank and with high efficiency. Aerobic granular sludge is currently used at full scale in sequential batch reactors, research for identifying the optimal solutions for continuous flow systems being carried out worldwide. The paper summarizes the results obtained for two continuous flow configurations with aerobic granular sludge, in terms of organics and nutrients removal for synthetic wastewater in laboratory conditions. Both experimental setups led to wastewater treatment efficiencies, with values ranging between 80 and $99 \%$ for COD, 85 and $99 \%$ for $B O D_{5}, 52$ and $98 \%$ for $\mathrm{NH}_{4}^{+}$and 5 to $87 \%$ for TP.
\end{abstract}

Keywords: Aerobic granular sludge, continuous flow, wastewater treatment

Wastewater treatment has the purpose of reducing pollutants concentrations in the treated effluents until they meet acceptable values that don't lead to receiving waters eutrophication and to changes of the natural water bodies [1]. The maximum loadings in the treated wastewater prior to its evacuation in natural bodies are given by the current legislation and depend on the receiving water body quality and further use [2].

Biological processes are widely used for reducing organics and nutrients concentrations from wastewaters, most often activated sludge flocs representing the basic treatment unit [3]. Although the activated sludge systems are usually able to provide good treatment performances, sometimes the need for upgrading the existing wastewater treatment capacity occurs as a result of unforeseen daily flow increase (due to population growth) or influent quality changes. One of the currently studied upgrading alternatives envisages replacing activated sludge flocs with aerobic granular sludge, dense and compact structures with increased settle ability and high organics and nutrients removal efficiencies [4]. Among the advantages of the granular sludge, the lower production of excess sludge reduces the necessary capacity and operational costs of the sludge treatment line [5].

Simultaneous organics and nutrients removal by using aerobic granular sludge is possible due to their layered structure. Aerobic granular sludge has an external aerobic layer followed by an anoxic one and an anaerobic core, facilitating the possibility for nitrifiers, denitrifiers and facultative anaerobic organisms to co-exist in one tank [68].

Nowadays, aerobic granular sludge is implemented at full-scale only in sequential batch reactors which are known to ensure the specific necessary conditions for granules formation and long-term structural stability. The extent of published papers on full-scale functionality and efficiency of aerobic granular sludge is limited to results obtained for granulation in full scale SBR systems with influent consisting in either $30 \%$ domestic and $70 \%$ industrial wastewater [9], either mainly raw municipal wastewater [10].
Current researches on continuous-flow reactors with aerobic granular sludge are focused on evaluating different reactors configurations for obtaining granules and maintaining their stability. Studied configurations include continuous-flow reactor with two-zone sedimentation tank [11], a modular continuous flow reactor system constructed from a series of containers with various volumes [12] and few studies focusing on continuous flow configurations similar to the ones existing in wastewater treatment plants [13-15].

The research of this study focuses on the treatment performances of two different lab-scale reactor constructive configurations fed with synthetic wastewater.

\section{Experimental part}

The first continuous flow aerobic granular sludge configuration is a $2 \mathrm{~L}$ rectangular shape reactor (R1) designed to perform as follows. The influent is introduced at the bottom of the bioreactor and comes into contact with the granular sludge biomass. Air is introduced at the bottom of the tank providing the aerobic conditions necessary for the metabolic processes involved in wastewater treatment and maintaining the fluidized bed movement. The bioreactor has a tilted lamella mounted at $a \sim 45^{\circ}$ angle against the bioreactor wall before the overflow area towards the granule recovery volume, which ensures that no air bubbles get in the pre-settling area and creates the optimal conditions for granules sedimentation. The granules passing over this blade decant in the granule recovery area and return to the active volume through an opening provided at the bottom of the granule's recovery area which communicates with the aerobic zone of the bioreactor. The granule recovery volume is protected from the aeration induced turbulence with a $\sim 3 \mathrm{~cm}$ lamella mounted on the reactor wall below the granule return opening at an angle of $\sim 45^{\circ}$. From the pre-settling and granules recovery zone, the effluent and the sludge with low settling abilities pass towards the secondary clarifier. All sludge separated in the secondary clarifier is considered excess sludge and is evacuated from the system while the effluent is collected.

*email: costel.bumbac@incdecoind.ro; Phone: (+40)214100377 
The second configuration tested (R2) is a $10 \mathrm{~L}$ rectangular shape reactor provided at the bottom with tilted walls to avoid dead-zones and granules sedimentation in the aeration tank corners. Two-thirds of the bioreactor bottom surface is covered with tubular aeration systems, the remaining area corresponding to a volume intended for sedimentation and granular return in the aerobic area. Near the tank bottom, in the granule recovery zone, a horizontal propeller-type mixer is installed with the purpose of redirecting the granules which are near the reactor bottom to the aeration zone, thereby creating two volumes of different velocity intensities in the same volume. Due to the inclined walls and the reduced tank section in the lower part of the active area compared to the upper section, the mixture flow rates are reduced at the top, facilitating the aerobic granules retention for entities with high settling abilities. The effluent is discharged by using a cylindrical settler foreseen with a degasser, designed in order to increase the separation efficiency.

Wastewater treatment performances were assessed based on the results of analytical determinations for organic load expressed both as chemical oxygen demand (COD) and as biochemical oxygen demand $\left(\mathrm{BOD}_{5}\right)$, total suspended matter (MTS), and concentrations of total Kjeldahl nitrogen (NTK), $\mathrm{NH}_{4}{ }^{+}, \mathrm{NO}_{2}{ }^{-}, \mathrm{NO}_{3}{ }^{-}$and $\mathrm{PO}_{4}{ }^{3} \cdot \mathrm{COD}$ was volumetrically analyzed using the potassium dichromate method according to ISO standard (SR ISO 6060: 1996). BOD was determined based on the amount of dissolved oxygen consumed within 5 days, under specific conditions, according to SR EN 1899/1,2-02 and DIN 38409-87. The total suspended matters were determined gravimetrically according to STAS 6953-81. Total Kjeldahl Nitrogen (TKN) was determined according to SR EN 25663-00. $\mathrm{NH}_{4}^{+}, \mathrm{NO}_{2}{ }^{-} \mathrm{NO}_{3}{ }^{-}$and $\mathrm{PO}_{4}{ }^{3-}$ were determined according to SR EN ISO 14911: $2003^{4}$ and SR EN ISO 10304/1: 2009 using the ICS-3000 ion chromatography system (Dionex, USA).

\section{Results and discussions}

Considering the constructive differences between the two continuous flow aerobic granular sludge bioreactors, the treatment performances were monitored to verify that the desired treatment efficiencies were obtained. Both aerobic granular sludge characteristics and biological process performances were monitored for 12 weeks.

For both bioreactors the active inoculum consisted in aerobic granules resulting from lab-scale sequential batch reactors fed with industrial wastewater.

Two different lab scale reactors were developed and fed with identical synthetic wastewater, containing sodium acetate, $\mathrm{NH}_{4} \mathrm{Cl}, \mathrm{K}_{2} \mathrm{HPO}_{3} \cdot 3 \mathrm{H}_{2} \mathrm{O}, \mathrm{CaCl}_{2}, \mathrm{MgSO}_{4} \cdot 7 \mathrm{H}_{2} \mathrm{O}$, FeSO $\cdot 7 \mathrm{H}_{2} \mathrm{O}$ and microelements (influent loading evolution throughout the experiments being shown in fig. 1).

COD removal efficiency profile is shown in figure 2. The removal efficiency for COD was maintained above $80 \%$ throughout the experimental period even though influent loadings varied between 330 and $820 \mathrm{mg} / \mathrm{L}$.

With maximal $B O D_{5}$ effluent concentrations of $20 \mathrm{mg}$ $\mathrm{O}_{2} / \mathrm{L}$, respectively $23 \mathrm{mg} \mathrm{O}_{2} / \mathrm{L}$, both bioreactors configurations met the treatment requirements in the national legislation. $\mathrm{BOD}_{5}$ removal efficiencies ranged between $85 \%$ to $99 \%$ for reactor R1 and $87 \%$ to $99 \%$ for reactor $\mathrm{R} 2$, respectively.

Organics removal performances were stable throughout the experiments, showing that microorganisms adapted to the new configuration and operational conditions including the change in feeding regime.

Nutrients removal is essential due to their adverse effects towards the environment if evacuated in high concentrations into receiving water resulting in eutrophication and overall water quality decrease. Ammonia removal efficiency was above $97 \%$ throughout

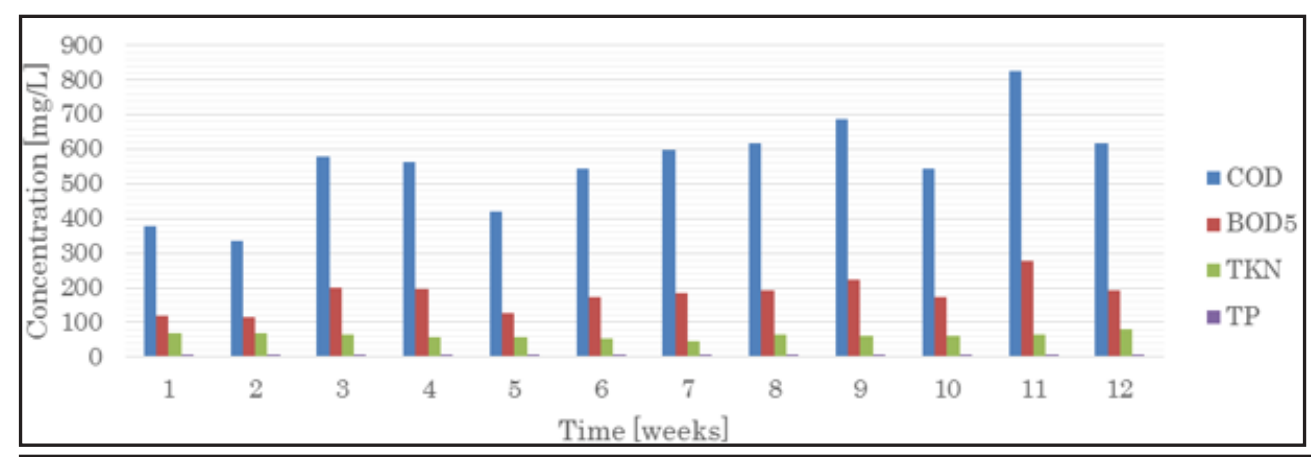

Fig. 1. Influent loading rates

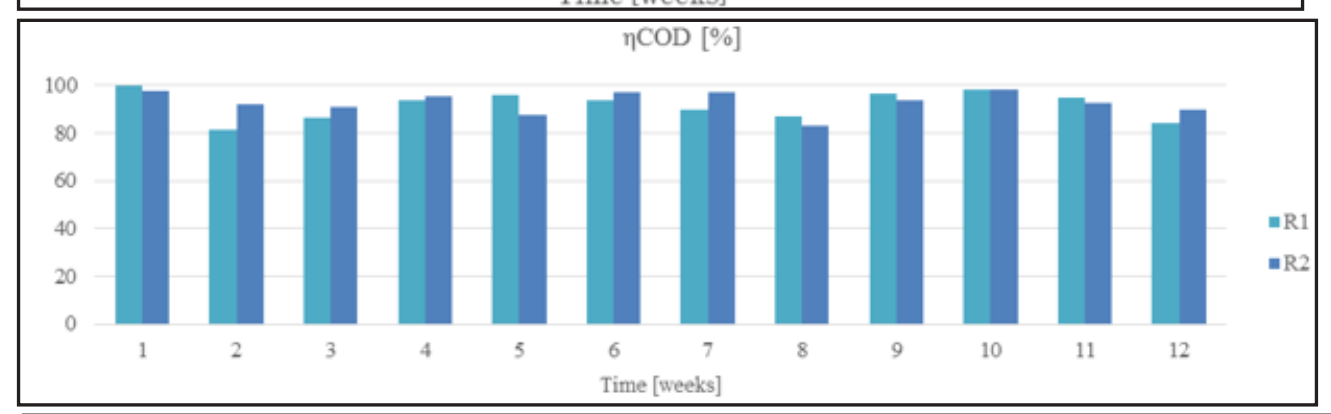

Fig. 2. COD removal

efficiency for the two continuous flow bioreactors

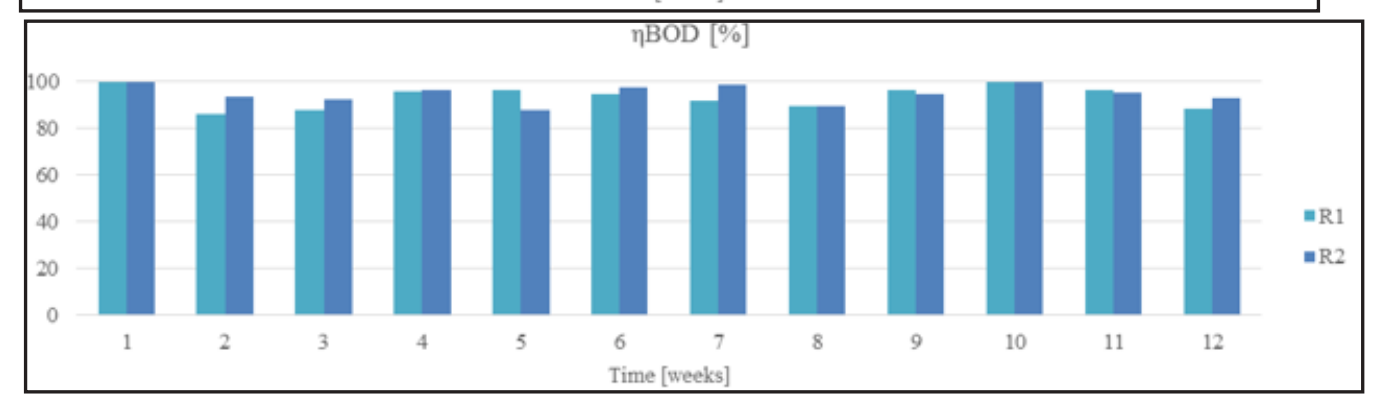

Fig. $3 \mathrm{BOD}_{5}$ removal efficiency for the two continuous flow bioreactors 


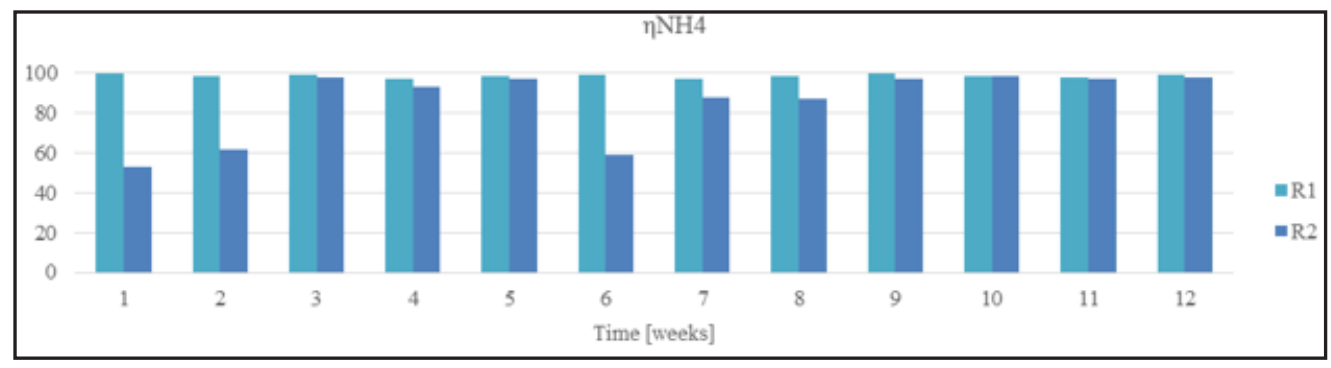

Fig. 4. Ammonia removal

efficiency for the two

continuous flow bioreactors

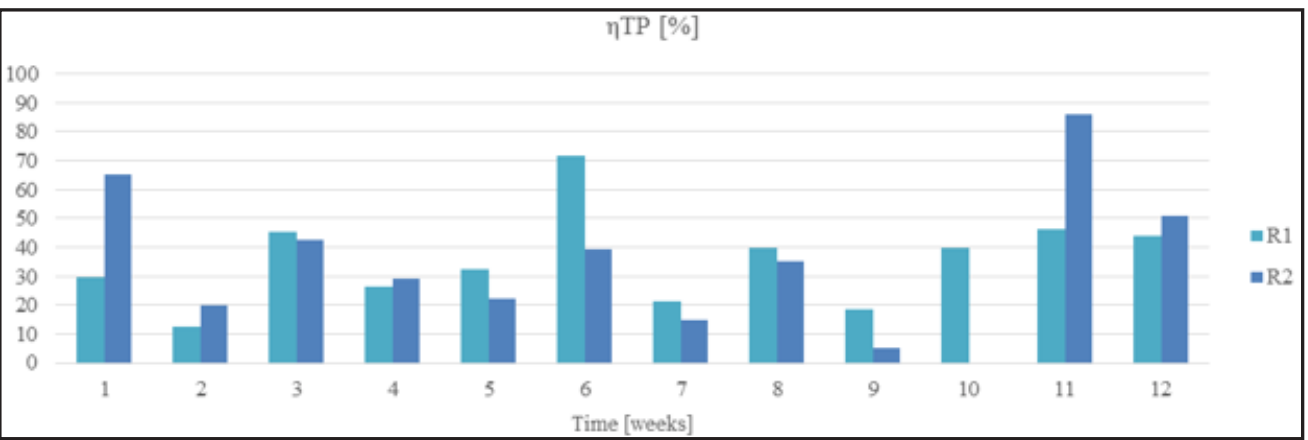

Fig. 5. TP removal efficiency for the two continuous flow bioreactors

the experiments for bioreactor R1, while in R2 stability (efficiencies exceeding $97 \%$ ) was achieved during the final four weeks of operation.

The good transformation of ammonia to nitrite can be due to the nitrifying bacteria contents of the granules and the intensive aeration of the mixture. The differentevolution among the two different configurations can be justified by the different hydraulic regimes and adaptation of the aerobic granular sludge to the continuous flow conditions, instead of the feast/famine condition in the sequential batch reactor.

Even though both reactors achieved high nitrification rates (as expected in an aerobic system), overall nitrogen removal did not exceed $65 \%$, probably due to the low organics concentration within the reactors at any given time as a result of the continuous feeding.

Total Phosphorous (TP) removal efficiencies varied between 12 and $71 \%$ in the first bioreactor's effluent and between 5 and $85 \%$ for the second one. Considering the layered structure of the aerobic granules, the low efficiencies and their evolution is justifiable by the low granules diameters and the granules recovery systems considered for the two continuous flow configurations.

\section{Conclusions}

The positive impact of using aerobic granular sludge is given by obtaining simultaneous organics and nutrients removal, reducing thus the energy consumption for the advanced wastewater treatment. Both bioreactors were foreseen with a granules recovery solution, both based on separating the granules with higher settling velocities and re-introducing them in the active treatment volume. The two designed and tested continuous flow aerobic granular sludge bioreactors led to promising results in terms of organics and nutrients removal efficiencies ( 80 to $99 \%$ for COD, 85 to $99 \%$ for $\mathrm{BOD}_{5}, 52$ to $98 \%$ for $\mathrm{NH}^{+}$and 5 to $87 \%$ for TP) while treating synthetic wastewater (COD $350 \div 830 \mathrm{mg} \mathrm{O} \mathrm{L}_{2}, \mathrm{BOD}_{5} 115 \div 280 \mathrm{mg} \mathrm{O} \mathrm{L}_{21}, \mathrm{NH}_{4}^{+} 26 \div 40$ $\mathrm{mg} / \mathrm{L}$, TP $6 \div 8 \mathrm{mg} / \mathrm{L}$ ) in laboratory conditions.

Acknowledgement $\div$ This work was supported by $P N \div 111 \div P 2 \div 2.1 \div P E D \div 2016$, UEFISCDI ProjectNo.12PED/201

\section{References}

1.STANILOIU, C., FLORESCU, C., Rev. Chim. (Bucharest), 65, no.4, 2014, p. 502.

2.WOINAROSCHY, A., SINGUREANU, C., Rev. Chim. (Bucharest), 68, no. 12, 2017, p. 2812.

3.ILIE, M., ROBESCU, D. N., GHITA, G., Rev. Chim. (Bucharest), 60, no. 5,2009, p. 529.

4.BUMBAC, C., MANEA, E.E., TIRON, O., BADESCU, V., Rev. Chim. (Bucharest), 69, no. 1, 2018, p.10.

5.MANEA, E.E., BUMBAC, C., TIRON, O., DINU, L.R., BADESCU, V., Rev. Chim. (Bucharest), 68, no. 8, 2017, p.1723.

6.PRONK, M., de KREUK M.K., de BRUIN B. , KAMMINGA P. , KLEEREBEZEM R., van LOOSDRECHT M.C.M., Water Research, 84, 2015, p.207.

7.GIESEKE, A., PURKHOLD, U., WAGNER, M., AMANN, R., SCHRAMM, A., Appl. Environ. Microbiol., 67, no. 3, 2001, p. 1351.

8.WINKLER, M.K.H., KLEEREBEZEM, R., KHUNJAR, W.O., DE BRUIN, B., VAN LOOSDRECHT, M.C.M., Water Res., 46, no.16, 2012, p. 4973. 9.LI, J., DING, L.B., CAI, A., HUANG, G.X., HORN, H., BioMed Research International, 2014, Article ID 268789.

10.PRONK, M., ABBAS, B., AL $\div$ ZUHAIRY, S.H.K., KRAAN, R., KLEEREBEZEM, R., VAN LOOSDRECHT, M.C.M., Appl. Microbiol. Biotechnol, 2015, p. 1.

11.ZOU, J., TAO, Y., LI, J., WU, S., NI, Y., Bioresour. Technol., 247, 2018, p.776.

12.DEVLIN, T., OLESZKIEWICZ, J., Bioresour. Technol., 253, 2018, p.281.

13.COFREA, C., CAMPOSB, J.L., VALENZUELA $\div$ HEREDIAB, D., PAVISSICHB, J.P., CAMUSB, N., BELMONTEC, M., PEDROUSOD, A., CARRERAD, P., MOSQUERA $\div$ CORRALD, A., VAL DEL RÍOD, A., Bioresour. Technol., 267, 2018, p.778.

14.MORALES, N., FIGUEROA, M., MOSQUERA $\div$ CORRAL, A., CAMPOS, J.L., MENDEZ, R., Sep. Purif. Technol., 89, 2012, p. 199.

15.DEVLIN, T.R., OLESZKIEWICZ, J.A., Bioresour. Technol., 253, 2018, p. 281.

Manuscript received: 12.08 .2018 